federal government to any new Province of the North. However, it can accurately be stated that the federal government does not ever plan to transfer ownership in these resources.

With regard to the ownership of natural resources and their transfer, Professor A. R. Thompson of the Faculty of Law, The University of Alberta, prepared and submitted an excellent brief which was all but ignored by the Carrothers Commission. With regard to Professor Thompson's submissions, the Commission said the following:

These submissions have been considered, but we consider that it would be premature to express an opinion on this question. ${ }^{14}$

In the end, therefore, and assuming that all of the recommendations of the Carrothers Commission are enacted into law (which is not likely), the North would continue at best to be a colony of the federal government with a Commissioner appointed by the Minister of Indian Affairs and responsible to the said Minister, not the legislature. If the evolution recommended by the Carrothers Commission does in fact occur, it can be hoped that it occurs within the next 100 years of Confederation.

The people of the North are unfaltering in their celebration of the Centennial. It is true that the North is part of Canada, but it is not part of Confederation.

$1+$ Id., at 208.

\title{
OWNERSHIP OF NATURAL RESOURCES IN THE NORTHWEST TERRITORIES
}

A. R. THOMPSON*

\section{THE HISTORICAL PRECEDENTS}

Development of natural resources is regarded as the key to economic and social development in newly self-governing countries. ${ }^{1}$ It was so regarded by our forefathers when the western provinces of Canada emerged to equality of status with the other Canadian provinces. The story of the political struggle through which these provinces wrested ownership of natural resources from the central government of Canada is a recent chapter in Canadian history-one that is told with authority by Chester Martin in his treatise on "Dominion Lands" Policy. ${ }^{2}$ It had its counterpart in the story of the political struggles by the Rocky Mountain states to gain control of mineral resources in the public domain in the United States, leading to the Mineral Leasing Act, $1920 .^{3}$ This Act of Congress continued federal control over mineral resources in the public domain, but it gave the fruits of exploitation to the regions and

* A. R. Thompson, B.A., LL.B. (Man.), LL.M. (Tor.), Professor, Faculty of Law, The University of Alberta. In 1967, Visiting Professor. Faculty of Law, University of Auckland.

1 U.N. Resolution No. 1803 (xvii) of 14 December, 1962, concerning Permanent Sovereignty over Natural Resources.

2 Part II of Volume II of the series Canadian Frontiers of Settlement, MacMillan, 1938. In particular, Chapter XII, entitled "The Natural Resources Question"; The Transfer of 1930, describes the attitudes and events leading to the natural resources transfer agreements of 1930 .

3 See, for example, Robbins, Our Landed Heritage, University of Nebraska Press, Bison Edition, 1962. 
states in which the minerals are located. A chapter is currently being written in Nigeria where a major element in the political upheavals is the contest between the federal government and the government of Eastern Nigeria over the exploitation of petroleum in the Niger Gulf.

The original provinces at Confederation provided in s. 109 of the British North America Act, 1867 each province should retain for its sole use the natural resources contained within its boundaries. When British Columbia and Prince Edward Island joined Confederation in 1871 and 1873 , they too retained natural resources. In fact, s. 109, together with s. 92 of the British North America Act, 1867 which entrusted the management and sale of the public lands to the provinces, were intended to establish the exploitation of natural resources as a major bulwark of the provincial economies.

However, when Canada acquired the western territories from the Hudson's Bay Company shortly after Confederation, and it was resolved to create a new province named Manitoba in the region of the Red River Settlement, Parliament decided to withhold from the new province the ownership and control of its natural resources. Sir John A. Macdonald believed that the western lands had to be retained by Canada to underwrite railway building and settlement, and his views won expression

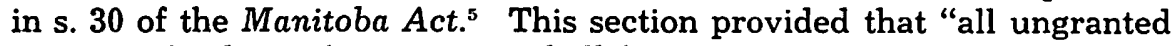
or waste lands in the province shall be ... vested in the Crown, and administered by the Government of Canada for the purposes of the Dominion. .." When, in 1905, the provinces of Alberta and Saskatchewan were carved out of the western territories, Parliament followed the Manitoba precedent and withheld natural resources for federal ownership and administration.

This absentee federal ownership led to much bitterness of feeling in the western provinces, arising from charges of inefficient and partial administration by Ottawa, and of colonial exploitation by eastern Canada. One writer advanced the western cause in the name of "Home Rule for Alberta"! The political struggles eventually led Parliament to concede the justice of the claim that the western provinces should be placed on an equal footing with the other provinces of Canada, and Royal Commissions were appointed to determine just what this footing should be. The report of the Turgeon Commission in 1929 led to the natural resources transfer agreements of $1930 .^{-}$By these agreements, the ownership and administration of natural resources in Alberta, Manitoba and Saskatchewan, and in the Railway Belt and the Peace River block of British Columbia, were transferred from the federal government to the respective provincial governments. It was stipulated that the federal government should account to the respective provinces for the value of these resources as if Canada had been a trustee of them. The Royal Commissions were entrusted with the task of accounting, and their re-

4 This subject is treated by the present author in Petroleum Land Policies Contrasted, 36 Color L. Rev. 187 (1964), and see post, at 311.

5 S.C. 1870, c. 3 .

6 A. Bramley-Moore, Canada and Her Colonies or Home Rule for Alberta, W. Stewart \& Co., 1911.

7 Alberta Natural Resources Act, S.C. 1930, c. 3; S.A. 1930, c. 21: Manitoba Natural Resources Acts, S.C. 1930, c. 29; S.M. 1930, c. 30: Saskatchewan Natural Resources Acts, S.C. 1930, c. 41; S.S. 1930, c. 87: The Railway Belt and Peace River Block Acts, S.C. 1930, s. 37; S.B.C. 1930 , c. 71 . 
ports closed a chapter in Canadian history ${ }^{8}$-but not without a final skirmish.

The Province of Saskatchewan insisted that the transfer agreement of 1930 include a provision that, whereas Saskatchewan contended that before the province was constituted in 1905 and entered Confederation, the government of Canada was not entitled to administer natural resources other than for the benefit of the people within the area, therefore a reference should be made to the courts to determine whether Canada had to account to Saskatchewan for its management of resources between 1870 and 1905 as well as after 1905. This claim to the benefit of resources in the name of the people of the region independently of their political and constitutional status finds support today in the United Nations resolution of 14 December, 1962 respecting sovereignty over natural resources, for this resolution asserts this sovereignty in the name of peoples and nations. One commentator explains this wording as a deliberate recognition that this sovereignty over resources is the entitlement of peoples who have not yet reached statehood. ${ }^{\circ}$ But when the agreed reference was carried forward, the Privy Council ruled against Saskatchewan's assertion. ${ }^{\text {io }}$ This judicial precedent established that the period during which the federal government had to account for its administration of resources was limited to the period after the region acquired provincial status. The ruling was applied to limit the accounting in the cases of Alberta and Saskatchewan to the period after 1905, and in the case of Manitoba, to the period after 1870.

\section{SELF-GOVERNMENT FOR THE TERRITORIES}

History does repeat itself. The remaining northern territories of Canada are now emerging to claim self-governing status, and they, too, assert that control over the exploitation of natural resources is the key to an independent and viable economy. Their claims, too, have been met by the appointment of a commission-in this case the Carrothers Commission, charged to make recommendations to the federal government on the development of government in the Northwest Territories. Recently, the report of the Commission was made public..1 Expectedly, it has recommended changes in the organization of territorial government so as to lead to provincial status for portions of the territories, following a period of increasing self-government and a review of the situation in 10 years' time. The first steps in implementing these recommendations have been announced by the government. ${ }^{12}$

With respect to natural resources, the Carrothers Report contained the following recommendation:-

(d) Ownership of Natural Resources

This report refers earlier to the question of transfer of subsurface rights from the federal crown to the territorial government. In our judgment it would be

8 See, for example, Report of the Royal Commission on the Natural Resources of Alberta, 1935 (The Dysart Commission).

- Mughraby, Permanent Sovereignty Over Oil Resources, Middle East Research and Publishing Centre, Beirut, Lebanon, 1966, at 40.

10 In re Transfer of Natural Resources to the Province of Saskatchewan, [1932] A.C. 28.

11 Carrothers Report on the Development of Government in the Northwest Territories, Queen's Printer, 1966.

12 Statement by the Honorable Arthur Laing, Minister of Indian Affairs and Northern Development, at Yellowknife, Northwest T.rritories, January 18, 1967. 
premature to make the transfer at this time. We recommend, however, that surface rights to land in and adjacent to settlements be appropriated.

We also received submissions that the federal government establish a system of accounting through which revenues derived by the federal government from the Northwest Territories in excess of expenditures would be transferred to the territorial government at the time it obtained control of subsurface rights. These submissions have been considered, but we consider that it would be premature to express an opinion on this question.

The Carrothers Commission could not have been unmindful of the crucial significance of mineral resource ownership to the economic development of the north, and of the intimate connection between economic development and social and political development. In the interests of self-government in the north, one is uncertain whether to applaud or to condemn this recommendation. One may lament that it merely postpones the inevitable and thereby delays the development of stable government in the north. On the other hand, the mere mention by the Commission of the possibility of a future federal accounting for natural resources contains a tacit assumption that ownership of these resources will some day be transferred to the territorial governments. Even the acceptance of this assumption would be a major gain for self-government in the territories. For, if the politicians and civil servants accurately reflect majority public opinion in Canada, there is currently no evidence of a will to accept the historic inevitability of an eventual transfer of resources to the territories. To the contrary, the Minister of Indian Affairs and Northern Development places an interpretation on this recommendation of the Carrothers Report which indicates that he would yield self-government to the north only on terms of economic vassalage.

He states that:

There is one other major approach in the Carrothers Commission Report which I accept without any qualification, and that is the continued sole responsibility of the Federal Government for northern resources. These resources are held by the Government of Canada for all of the people of Canaja. All Canadians through the Government of Canada and through private enterprise have contributed heavily to the development thus far. They will do so far more generously in the future (based largely on the investment and taxation of people south of the 60th parallel) and it is in the interests of Canadians, both in the north and south alike, that Canada as a whole shoulder the costs and share the benefits of the great developments which may be expected.13

The Deputy Minister goes so far as to suggest that the key to national unity in Canada may be the common interest which Canadians have in exploiting northern resources. ${ }^{14}$

Official policy therefore stands as a declaration of continued federal suzerainty over the north notwithstanding the proffered evolution to provincehood. Flying in the face of historical precedent in Canada, this policy requires that the strongest reasons be put forward in its support. In this writer's opinion, no adequate reasons exist.

\section{INADEQUACY OF REASONS ADVANCED IN SUPPORT OF FEDERAL OWNERSHIP}

Historians have noted three reasons offered as justifying the retention of natural resources by the federal government when the new provinces were being formed in western Canada.

13 Ibid.

14 Speech by E. A. Cote, Deputy Minister of Northern Affairs, as reported in The Ottawa Journal. 
1. Dominion purposes: Historians accept that the building of a railroad and settlement of the prairies were essential if Canada was (sic) to survive, and that control of the land was basic to the attainment of these objectives. Such paramount purposes of the Dominion were given precedence over the "principle, widely if not universally followed in British democracies, that natural resources should be administered and controlled by the province in which they lie, for the revenue and other purposes of that province.14a

It is difficult to imagine any such compelling "dominion purposes" today when Canada prospers as a modern industrialized nation. Surely "national unity" demands a more sophisticated foundation than that Canadians should share the wealth of northern exploitation. In any event, the practiced and logical way in which Canadians share the wealth is by dominion-provincial tax agreements whereby regional wealth is equalized throughout Canada in support of national standards of public welfare services.

2. The purchase theory: Canada was required to pay to Great Britain the $\$ 300,000$ price for acquiring from the Hudson's Bay Company its holdings in the territories. Control over the lands of the new provinces created out of the territories was regarded as a means of securing repayment to Canada of this purchase price.

This theory was first advanced in the United States to support the case for continued federal ownership of the public domain lands which were located in the western territories and Alaska, acquired by purchase from France and Russia, respectively. Its eclipse is revealed by the liberal terms of statehood given Alaska, which received for its own purposes almost one-third of the public domain lands and $90 \%$ of the revenues derived by the federal government from the remainder. The purchase theory never was convincing in Canada. From the legal viewpoint, Canada never had acquired title to any lands in the west by purchase, for the Hudson's Bay Company had surrendered its rights to Rupert's Land back to the Crown, and Great Britain had then transferred the administration of Rupert's Land and of the north-western territories to Canada. Throughout, title remained in the Crown, one and indivisible for Great Britain, Canada, and for Rupert's Land and the unexplored territories to the west and north. ${ }^{15}$

As a modern counterpart to the purchase theory, the Minister of Indian Affairs and Northern Development would liken the investment by the Government of Canada and by private industry in northern development to a purchase price entitling the people of Canada to proprietorship in perpetuity over northern resources. The obvious weakness of this reasoning is that it equally would entitle foreign investors to absolute ownership of petroleum in Alberta and of iron ore in Labrador, for it is their capital funds that have developed these resources. Neither is the argument convincing in terms of equivalence of benefit. The Minister states that in 1964-65 the federal subsidy to the Northwest Territories was $\$ 13$ million. This not insubstantial sum pales in comparison to the revenues which are anticipated should petroleum deposits, to mention one mineral resource, measure up to expectations. Potential petroleum reserves are likened to those in Alberta where lease sales alone earned the provincial government in excess of $\$ 100$ million in 1966, with a similar amount being earned in rentals and royalties. It is surely fairer to the people who will inhabit a province of the north 
that their resources should be transferred to them after an accounting which has recognized their indebtedness to the Government of Canada, arising from the present period of federal subsidy.

3. Efficient administration: It was sometimes maintained that in the public interest the new provinces were not "ready" to provide efficient administration of natural resources.

The record of resource administration in North America does not support a charge that regional governments are less solicitous of the public interest or more prone to inefficiency in the handling of resources than is a central government. Rather, there is much evidence that the more experienced and proficient administrations in the petroleum and mining industries have evolved at the state and provincial levels.

The submissions made by Counsel for the Province of Alberta to the Dysart Commission in 1935 contained much evidence of inefficiency in the handling of "under rights" and in the collection of surface rentals and fees by the federal Department of the Interior. The history of the public domain in the United States is replete with instances of dishonesty and corruption with respect to lands administered by federal agencies. ${ }^{13}$ Chapter and verse can be cited to expose any folklore that would place on a pedestal federal administration over regional administration in terms of efficiency and honesty. Today, as examples of modern policies and efficient administration of mineral resources in the United States, the writer would cite the Alaska Division of Lands and the California State Lands Commissions. In Canada, the mines and minerals departments of the Provinces of Alberta and Ontario may be mentioned for experienced personnel and sophisticated policies.

But, rather than prolong an unseemly contest respecting the relative merits of federal and provincial administration, it is more significant to note that today there are experienced, qualified and diligent personnel in the resource development field who are being recruited for service in remote parts of the world, and there seems no compelling reason why government in northern Canada should not be able to attract its share of these people.

Two other reasons may be advanced today for retaining federal control of natural resources.

4. The revenue reason: The Canadian government should retain ownership of national resources in the north to maximise revenues as an offset to the federal subsidies which will be required to provide the citizens of the new self-governing parts of the Territories with health and welfare standards equal to those in the rest of Canada.

Apart from its implications for the other provinces of Canada which receive federal equalization payments and subsidies, this reason fails because the facts do not support its premise that federal administration would be likely to realize greater revenue from resources than a provincial administration. The Dysart Commission had this question of revenues directly before it, and concluded that "Taking the whole period, 1905-1930, into account, we think that a provincial administration would have succeeded in obtaining from the mineral resources, in the aggregate, a net revenue considerably larger than that which the Dominion,

16 Robbins, Our Landed Heritage, Bison ed., 1962. 
less intent upon revenue purposes, actually derived". ${ }^{17}$ The same assessment that revenues have been a subordinate consideration can be made of the administration of the public domain in the United States by the federal Department of the Interior. ${ }^{18}$

5. The economic planning reason: The resources of the north can best be developed under a central authority administering common policies for all of Canada.

This reason has in support that there are matters of policy with respect to the development of resources that are of national import. Fiscal policies and policies with respect to taxation and trade are a few of these. But this economic planning reason would designate ownership of resources as the instrument for accomplishing such policies, and in so doing it would violate the basic constitutional organization of Canada. This reason would equally justify federal ownership and control of the mines of Ontario and Quebec. Canadian constitutional development, whatever future changes there may be, dictate that for the foreseeable future the federal spheres of policy must be realized otherwise than through ownership and control of natural resources.

\section{THE TRUSTEESHIP OF THE FEDERAL GOVERNMENT}

Dictating a trusteeship role for the federal government rather than beneficial ownership of natural resources of the Territories are the various precedents which have already been mentioned-the precedents of British colonialism, of the settlement reached between the prairie provinces and the federal government by the transfer agreements of 1930 , and of the agreements for allocation of revenues from the public domain reached between the state and federal governments in the United States. Two issues are posed by this trusteeship: (i) when it begins, and (ii) how the accounting is to be effected.

1. When the trusteeship begins: The Saskatchewan reference established that the federal government was bound to an accounting only from the time when the province was created in 1905 . This precedent may well preclude a claim by a newly-created province in the Territories to an accounting for the exploitation of natural resources during the period of federal administration prior to the date when the new province is created.

Nor are there moral or practical grounds for a claim to an accounting with respect to past administration. The report of the Dysart Commission shows how elusive is the concept of equality among the Canadian provinces as to resources which have been so unequally bestowed, ${ }^{19}$ and it shows how impractical is the task of determining ex post facto how much compensation should be awarded. ${ }^{20}$ But these very difficulties are those which make it imperative that the manner of accounting be determined as an early step in the evolution of self-government in the Northwest Territories.

The Carrothers Commission has concluded that it is now premature to express an opinion on the question of accounting, but the lesson taught by history is that equity and practicality require that the answer to the question not be postponed.

17 Ante, n. 8, at 33

18 The present writer, Petroleum Land Policies Contrasted, 36 Color. I. Ru.v. 187, at 218-219.

10 Ante, n. 8, at 16

20 Ante, n. 8, at 37 (Point $\mathbf{E}$ of the Report). 
Arthur Meighen, then Prime Minister of Canada, said the prairie situation:

It is not a hard matter to scramble an egg but it is a very hard matter to unscramble it. It was not a hard matter to retain the resources, but once you have retained them for fifteen to twenty years and adjusted every phase of public policy to the fact that there was retention, then it becomes a matter of very great complexity.

In the Turgeon Commission Report, which deals with Manitoba's case, there is the following comment:

... we cannot do better than to go back to the beginning and endeavour to do now what ought reasonably to have been done in 1870 if the spirit of the Orderin-Council had then governed those in authority. If the idea had then been accepted that Manitoba was entitled to occupy, in respect to its public lands, a position of equality with the other Provinces of Canada, but that, nevertheless, these lands had to be surrendered to the Dominion for reasons of paramount national importance, arrangements would have been made at once to compensate the Province suitably and adequately for the loss.

2. How the accounting is to be done: The Turgeon and Dysart Commissions revealed how difficult is the task of accounting for resources at the end of the period of trusteeship when no guidelines have been established in advance. Establishing such guidelines is clearly one of the most important contributions that can be made towards the founding of a responsible and economically viable province in the Territories.

Such guidelines are likely to be somewhat arbitrary in nature to be practical in operation. It should be possible to reach agreement on satisfactory accounting methods. If not, surely agreement could be reached along the lines of the political settlements in the United States. There, in the administration of the public domain, experience proved that an acceptable allocation of revenues from sales, bonuses, royalties and rentals of public lands under the Mineral Leasing Act, $1920^{21}$ is $10 \%$ to the federal government for administration expenses, $371 / 2 \%$ to the state within the boundaries of.which the leased minerals are located, and $521 / 2 \%$ to the fund established under the federal Reclamation Act for the reclamation of the arid lands of these states. In Alaska, where the reclamation scheme does not operate, the state's share is $90 \%$.

\section{CONCLUSION}

If those responsible for policy in the Northwest Territories have no present intention of affording to northerners a steady evolution to provincehood on an equal footing with other citizens of Canada then their positions should at once be forthrightly stated and supported. If, on the other hand, self-government is an assured destiny for the north, it is almost inconceivable in the light of experience in Canada and elsewhere that the new territorial government should long be deprived of natural resources. Policy should now be shaped in the mould of precedent. It is submitted that it is not premature for the federal government now to acknowledge its role as a trustee of natural resources for the future governinent of the Territories, and it should establish the guidelines for a proper accounting of that trusteeship when it comes to a close.

2130 U.S.C. 